\title{
International Forestry Working Group
}

International Activities at the University Forestry Schools of Canada*

Based on 1982 figures, there were 81 foreign undergraduate students enrolled out of a total of $1914(4.2 \%)$. However, almost a quarter (79 out of 337) of the graduate students were from outside Canada. Laval had the highest undergraduate enrollment $(10.1 \%)$, whereas the University of British Columbia had the highest graduate enrollment (32\%). Africa, Europe and Asia had the highest representation. Silvics, forest ecology and forest biology were the most popular programs of study.

Only eight of the 258 Canadian graduate students were taking research on forestry problems outside Canada.

Of the academic staff, $46 \%$ undertook professional assignments outside Canada during $1977-1982$ and $86.9 \%$ of these assignments occurred in Africa (25.1\%), Europe $(26.0 \%)$ and the United States (35.8\%).

Two of the forestry schools have formal agreements with universities outside Canada. Laval has an agreement with the Institut Agronomique et Vétérinaire in Morocco, and the University of Toronto, through CIDA, is establishing a master's program in forest science at the National Agrarian University in Lima, Peru. There are a number of informal arrangements, such as the 3rd year student exchange between Lakehead University and the Netherlands, and efforts by the University of Alberta to consolidate relations with Japan, Korea and the People's Republic of China.

Involvement at the international level is expected to increase in future years. The University of Alberta has established an Associate Vice President responsible for international relations and funds are being provided to establish international contacts and support for third-world students. Laval is adding a two-year master's program in international forestry. The emphasis will be on tropical, equatorial and mediterranean forestry, cultural and sociological training. At the University of Toronto, a twinning arrangement is being considered with the Federal University of Vicosa, Brazil. A new undergraduate course in world forestry is also being established to augment the existing postgraduate courses "Forestry in the Developing World" and "Tropical Moist Forests". A one-year diploma course is available in International Forestry Studies.

\section{G.A. Steneker}

Secretary CIF International Forestry Working Group

\footnotetext{
-Paper: Nordin, V.J. 1984. Activities and Linkages in International Forestry at the University Forestry Schools of Canada. Proceedings of Society of American Foresters.
}

\author{
New Forest Damages in the \\ Federal Republic of Germany
}

Since the late 1970's, large-scale forest damage has been observed in the Federal Republic of Germany. Silver firs have been particularly affected, but damage symptoms have been increasingly found on spruce, pine and beech, and even such species as oak, maple and ash

Although there are many unanswered questions as to causal agents, a panel of experts for environmental questions concluded in their report of March 1983 that emitted pollutants (e.g. $\mathrm{SO}_{2}, \mathrm{NO}_{\mathrm{x}}$, photooxidants), together with other pollutants and/or causal agents (e.g. climate, pests, etc.) play a decisive role.

The forest damage survey of 1983 showed that damage from known and unknown causes extended over $43 \%$ of the forest area; this compared with only $8 \%$ shown by the 1982 survey. Although poor weather conditions and better survey techniques in 1983 may have been partly responsible for the increase, nonetheless, the situation seems to have deteriorated drastically.

Hardest hit are the silver firs with about $75 \%$ showing damage, followed by pine $(44 \%)$, and spruce $(41 \%)$. Damage to broadleaved species is less

The Republic is not the only country affected. There are indications that in other central European countries, varying degrees of increased forest damage are occurring. Serious problems are foreseen for the timber market as a result of increased salvage cuttings and the management of otherwise healthy stands as a consequence of priority harvesting.

\section{G.A. Steneker} Secretary

CIF International Forestry Working Group

\section{Second Meeting of the CIF International Forestry Working Group}

The second meeting of the International Forestry Working Group (IFWG) of the Canadian Institute of Forestry (CIF) was held in Quebec City on August 7, 1984, on occasion of the CIF/SAF/IUSF International Forestry Conference.

The business meeting was preceded by a joint SAF/CIF technical session, chaired by John Yavorsky, Dean of the School of Continuing Education at the College of Environmental Science and Forestry, SUNY at Syracuse. Dr. Yavorsky is also Chairman of the IFWG of the SAF
The program consisted of four presentations:

1. 'Policy and Legal Aspects of Agroforestry Planning and Development', by Dr. Howard Stepler, Plant Science Department, Macdonald College, Quebec.

2. 'Policy and Legal Aspects of Mangrove Forests Management', by Dr. François Blasco of Université Paul Sabatier, France.

3. New Dimensions in the Policy and Legal Aspects of Forestry Land Management', by Ms. Margaret Shannon, Resource Policy Consultant, U.S.

4. 'Policy Incentives for the Management of Tropical Forests', by Dr. Marc Dourojeanni, Universidad Agraria, Peru.

In the absence of Dr. Blasco, his paper was presented by Claude Gendreau of the Canadian Forestry Service.

All four speakers stressed the importance of land management rather than management specifically for forestry. Dr. Stepler pointed to the close links between forestry and agriculture and saw agroforestry as a viable management option, particularly in light of the heavy stress in many countries, both on the food chain and fuelwood requirement. It was seen as a land management option rather than as an option for forest or agriculture policy.

Dr. Blasco, in his paper, pointed to the rapid destruction of natural mangrove forests and put most of the blame on the fact that, in most countries, too many ministries have part responsibility for their management, making it virtually impossible to effectively implement plans.

Ms. Shannon illustrated in her paper the gradual move from neutral decision making to political participation in forest resource management. Management plans must be much broader than those limited to tree resources only. Participatory planning is now occurring.

Dr. Dourojeanni painted a rather bleak picture of forest management in the tropics, particularly in South America. Although some changes for the better were noted, agricultural development was seen as a big culprit. The need was seen for better public opinion, more integrated management and greater utilization of wood and other products, simplified legislation and proper cost-benefit analyses.

The joint meeting was followed by a brief business meeting of the IFWG of the CIF, convened by R. Roberts, Chairman of the Working Group. Fifteen members attended this meeting.

The Chairman reviewed the creation and development of the Working Group since 1983. Present membership stands at about 40 .

Progress with the newsletter in the Chronicle, the principal undertaking of the Group at present, was considered very promising. There was no problem seen in obtaining material. Members were encouraged to send in their contributions 
to G. Steneker, Secretary to the Group, in the form of short "newsy" items of international interest, but also feature-length articles, such as trip reports, etc.

The Working Group is assisting the International Society of Tropical Forestry with the translation into French of its newsletter.

It was agreed that the Working Group should continue vigorously with and improve upon its newsletter, and continue with its assistance to the ISTF.
The idea was then tabled to develop a resource of audio-visual aides on international topics (e.g. country profiles). It was envisaged that a Working Group member may want to initiate such a project, and volunteers would be most welcome. (Please contact the Executive - R. Roberts, Y. Dubé or G. Steneker.)

The Working Group was also seen as a body that could provide assistance by way of advice to non-government organizations. The Baker Foundation, located at the
University of Saskatchewan, was noted as a good example. Although the joint CIF/ SAF meeting was seen as an excellent occasion for a joint meeting of the two International Forestry Working Groups, it was noted that joint meetings with the Working Group of the SAF could be called in the interim anytime it seemed productive.

G.A. Steneker Secretary CIF International Forestry Working Group

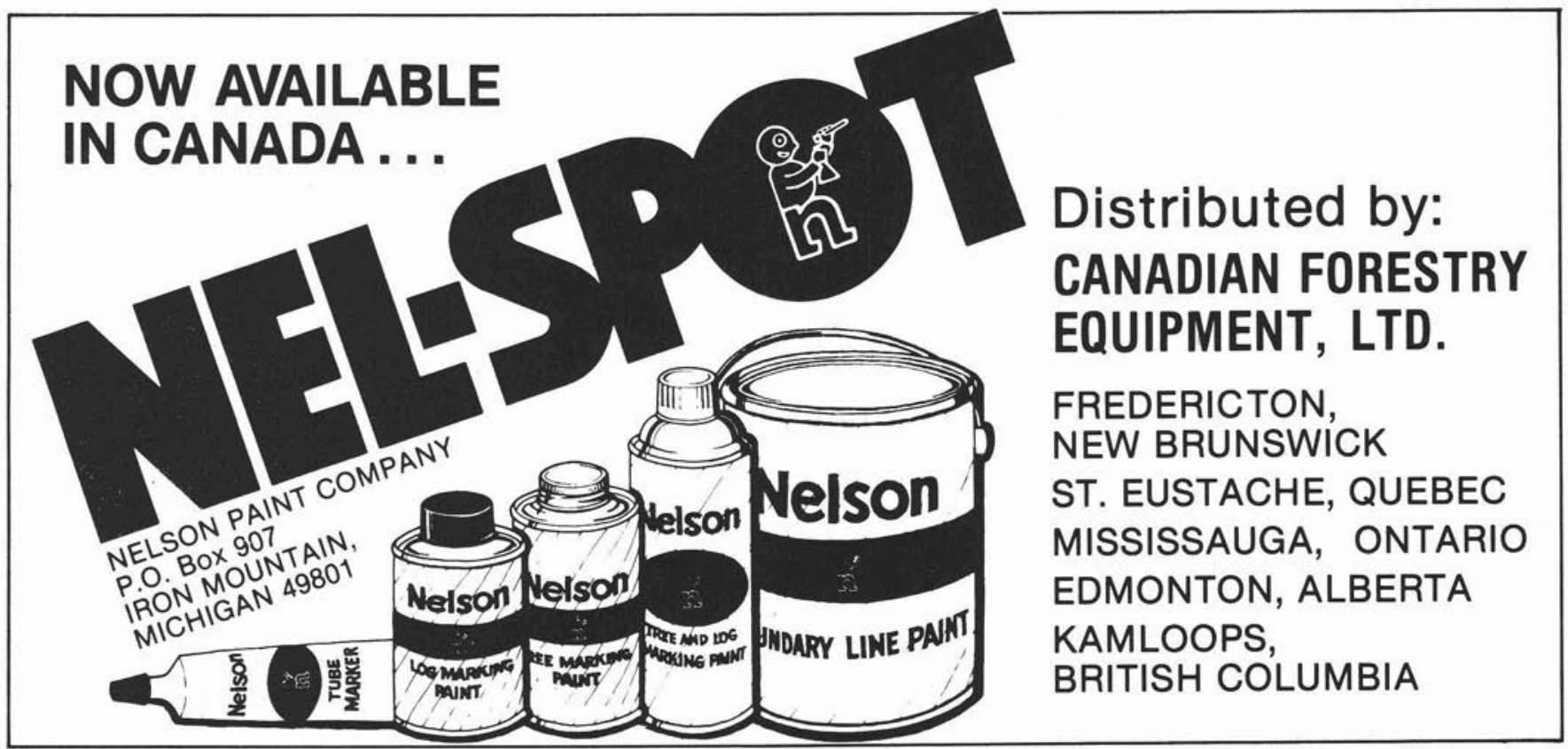

\section{EDWARD \\ S. FELLOWS}

FORESTRY \& FOREST PRODUCTS CONSULTANT

P.O. Box 354, 404 Queen St., FREDERICTON, N.B.

Registered Professional Forester (N.B.)
MEMBER:

Canadian Institute of Forestry

Forest Products Research Society, Etc.

INDUSTRY DEVELOPMENT - FOREST PRODUCTS ECONOMIC FOREST POLICY \& ADMINISTRATION 